\title{
The effect of the physicochemical conditions variations on the behavior of heavy metals trapped in polluted fluvial system sediments: the case of Oued Sebou, Morocco
}

\author{
H. Hassimi ${ }^{1,4} \cdot$ A. Taleb $^{3} \cdot$ M. Bouezmarni ${ }^{2} \cdot$ O. Karzazi ${ }^{5} \cdot$ M. Taleb $^{4} \cdot$ A. Kherbeche $^{1} \oplus \cdot$ V. Debbaut $^{2}$
}

Received: 14 December 2016 / Accepted: 1 January 2019 / Published online: 16 January 2019

(c) The Author(s) 2019

\begin{abstract}
This study was an attempt to understand the factors influencing the heavy metal distribution in polluted fluvial system sediments. Various biogeochemical processes and anthropogenic factors were playing an important role in altering the concentration of heavy metals in the sediments. This paper has two objectives: The first one is to investigate the effect of the variation in the physicochemical conditions on the speciation of trace elements trapped in the sediments of the Sebou River. The second one is to study the kinetics mobilization of these heavy metals. Batch resuspension experiments were conducted in order to investigate the release of heavy metals from a polluted anoxic sediment submitted to different physicochemical conditions variations. It has been revealed that in oxygenated environment, sediments were oxidized which cause the release of some heavy metals, but their concentrations, as dissolved phase, were sustained constant or were increased with time. However, in acidic and anaerobic environment, most of the metallic trace elements were released together with the iron and the manganese, but some of these elements like chromium were precipitated. However, some of other elements were maintained in solution, which represents a real human health risk.
\end{abstract}

Keywords Sediment $\cdot$ Heavy metals release $\cdot$ Resuspension $\cdot$ Speciation $\cdot$ Physicochemical conditions

\section{Introduction}

The overuse of Moroccan water resources and their degradation cause a disturbing shortage, threatening the socioeconomic development of the country. The development of human and industrial activities has long pursued at the

A. Kherbeche

kherbecheabdelhak@gmail.com

1 Present Address: Laboratoire "Catalyse Matériaux et Environnement", École Supérieure de Technologie, Université Sidi Mohamed Ben Abdellah, Route d'Imouzzer BP: 2427, Fez, Morocco

2 Département Sciences et Gestion de l'Environnement, University of Liège, Arlon, Belgium

3 Environmental Process Engineering Laboratory, Faculty of Science and Technology Mohammedia, Hassan II University of Casablanca, Morocco, Mohammedia, Morocco

4 Engineering Laboratory, Electrochemistry, and Modeling Environment, FSDM, USMBA, Fez, Morocco

5 Physics Department, Faculty of Sciences, LPS, BP 1796, Fez, Morocco expense of watercourses, considering that they could withstand indefinitely any industrial or municipal discharges. The consequences of this kind of management are then severe: A significant degradation of water surface quality is induced and an accumulation of the contaminants in the sediments is noticed (case of Sebou River in Morocco). Moreover, in the case of reaching the toxic levels, the heavy metals can affect the benthic organism and the food chain, which cause an increase in human health damage for the local population (Lourino-Cabana et al. 2010). It is well known that heavy metals are the most dreaded contaminants of the pollutants (Du Laing et al. 2009), because of their toxicity, abundance, environmental persistence and their possible bioaccumulation (Bourgeault et al. 2011). In fact, hypoxic conditions promote the extraction of a metal from its oxide and the increase in the dissolve fraction of some elements with numerous valence states like Fe and Mn (Duc et al. 2013); these heavy metals can be trapped in the sediments as various forms (linked to sulfides, carbonates, organic matter and oxyhydroxides) (Tessier et al. 1979). They could be released in the dissolved phase and become biodisponible (Lafabrie et al.2013), under the 
effect of the physicochemical conditions variations such as pH and dissolved oxygen (Kelderman and Osman 2007). This phenomenon depends on the way in which the metals were stored in the sediments and how they were related in the mineralogical phase (Kelderman and Osman 2007). When metals are released to the dissolved phase from suspended sediments, bioavailability probably increases and the risk to aquatic life is heightened (Cantwell et al. 2008). The total concentration of the heavy metals does not allow assessing the short-term environmental risks because they do not reflect their mobility, reactivity or bioavailability (Meers et al. 2005). This is why the sediments represent a potential threat against the aquatic biota and water quality. Unfortunately, the Moroccan Water Directive (sediment contamination legislation) has not yet considered this compartment. This is why studying the distribution of dissolved elements and especially of heavy metals in sediments seems to be important; indeed, speciation influences the behavior of these contaminants in the aquatic environment, including transport, persistence, toxicity and bioavailability (Kramer et al. 1988).
Sebou is the biggest river in Morocco with its 40,000 $\mathrm{km} 2$ catchment (Foudeil et al. 2013). This zone is the most populated (inhabitants of about 5.6 million) and contributes to $30 \%$ of the Moroccan potential surface water resources (Lamhasni et al. 2013). However, the Sebou River is one of the most polluted rivers in Morocco (Azzaoui et al. 2002). On its way, Sebou River crosses several cities and urban areas; among them, Fez is the most important [the subbasin of Fez alone generates $40 \%$ of pollution (Hayzoun et al. 2015)]. The rapid development of the industrial and the artisanal activities, the rapid urbanization, the population growth (population of 1 million), the inadequacy of controlled waste management strategies and the waste treatment plants in Fez have increased the dangerous pollution problems of the Sebou River (Perrin et al. 2014). According to Derwich et al. (2008), $341 \mathrm{~kg} / \mathrm{d}$ is the concentration of heavy metals daily, in which chromium is about $67 \%$, and is discharged from Fez to Sebou River, noting that its water is used for irrigation purposes of some agricultural areas, which present a real risk to the Sebou River ecosystem. Previous studies have been focused on water quality

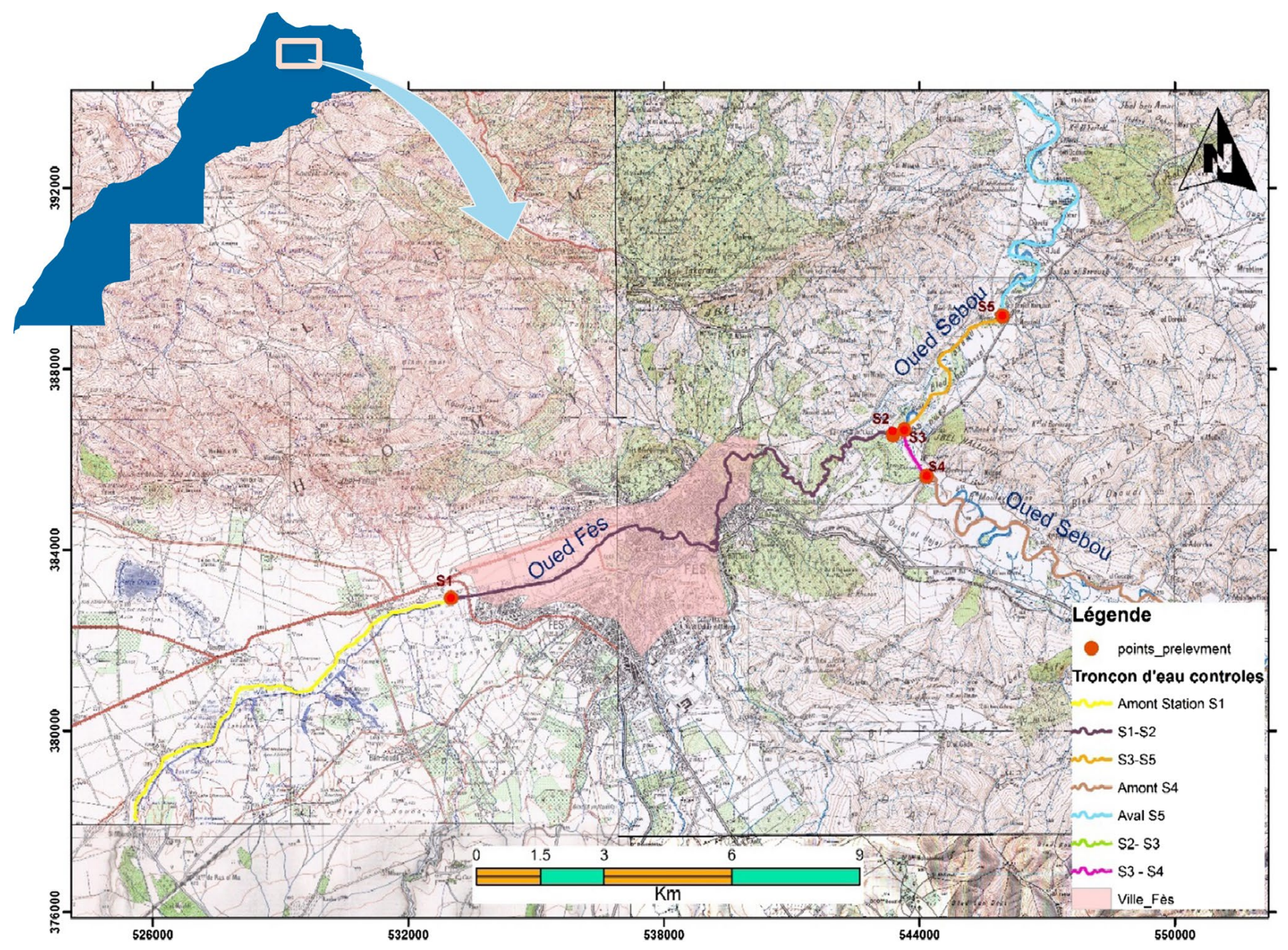

Fig. 1 Chart of localization of the various sampling<smiles>C1C2CC12</smiles>

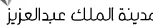

KACST 
by monitoring some physicochemical and bacteriological parameters (Koukal et al. 2007; Amri et al. 2007; Malki et al. 2008), but none of them has determined the speciation of those heavy metals in the sediments of Sebou River. The objective of this work is to investigate the factors affecting the speciation of heavy metal elements trapped in the sediments of the Sebou River and the mobilization kinetics study of these heavy metals. The method of the mobilization study was based on the simulation of mechanisms encountered in the water-sediment interface. The experiments were carried out in a reactor designed at the laboratory scale.

\section{Materials and methods}

\section{Study area}

The Sebou River is the biggest Moroccan river. It crosses approximately $600 \mathrm{~km}$ between its source at the Middle Atlas and the Atlantic. It can be divided into three distinct geomorphic catchments: the upper, the middle and the lower Sebou. The Sebou River originates from the Middle Atlas chain, which is characterized by a mild Mediterranean climate and predominantly calcareous-dolomitic bedrock. The mid-Sebou basin lies within the Rif and Prerif Mountains, characterized by an average altitude of $2000 \mathrm{~m}$. The climate of the Fez region is semiarid to temperate in winter and hot in summer. The Fez River flows in an easterly direction from the springs of "Ras el Ma" to the Sebou River, $4 \mathrm{~km}$ downstream of Fez City. Sebou River plays a vital role in supplying water for drinking, irrigation and industry to the Sebou watershed (Hayzoun et al. 2014).

Fez City (alone) generates $40 \%$ of the total impact of water quality on the Sebou River (Hassimi et al. 2016). The studied area has a continental semiarid climate with cold winter and hot summer. The winter period, between October and April, is the rainy season, while the remaining months are mainly dry (Hayzoun et al. 2014). The base flow of the river is around $17 \mathrm{~m}^{3} \mathrm{~s}^{-1}$ (Mutin 2009). The geological characteristic of Sebou River watershed includes clays and calcareous formations of the middle Atlas Mountains. Samples studied in this work were selected along the Sebou River and its junction with the Fez River, where the principal vector of pollution is noted (Fig. 1):

- Station No. 1: located on the Fez River before its entry to the city, considered as a reference station.

- Station No. 2: situated downstream of Fez City (Fig. 1), representing the converging area of all the effluents from Fez City before joining the Sebou River.

- Station No. 3: located between the confluences of Fez River with Sebou River.
- Station No. 4: situated on the Sebou River upstream of the confluence with Fez River; this reference station is not influenced by the pollutant emissions.

- Station No. 5: located on the Sebou Rivers at approximately two kilometers downstream of the junction with Fez River.

\section{Measurement and sampling protocols}

All materials in contact with the samples have been carefully decontaminated (24 h in HNO3) (Audry et al. 2010). Samples were manually collected approximately at $10 \mathrm{~cm}$ below the surface of the sediment and transported in a refrigerator to the laboratory in a bottle decontaminated. Measurements of the physicochemical parameters [temperature, $\mathrm{pH}$, dissolved oxygen (DO), electric conductivity (EC)] were performed in situ with a multi-probe (probe holder, standard, portable hach) calibrated before each campaign. For the determination of the total metal elements traces, all the sampling stations were dried at $80^{\circ} \mathrm{C}$, Then, they were crushed and sieved. After an aqua regia digestion procedure, the extracted liquid fraction was the subject of the later analysis; $10 \mathrm{ml}$ of aqua regia mixture of $\mathrm{HNO} 3$ and $\mathrm{HCl}$ (in a 1/3 ratio) was added to $2 \mathrm{~g}$ of

Table 1 Trace metal contents in the surface sediments and in situ measurements « of the physicochemical parameters (average of three replicas) of Sebou and Fez Rivers

\begin{tabular}{lllll}
\hline $\begin{array}{l}\text { Sample } \\
(N=3)\end{array}$ & $\begin{array}{l}\text { Sample } \\
\text { No. } 5\end{array}$ & $\begin{array}{l}\text { Sample } \\
\text { No. } 2\end{array}$ & $\begin{array}{l}\text { Sample } \\
\text { No. } 4\end{array}$ & Station No. 1 \\
\hline $\mathrm{pH}$ & 7.54 & 7.85 & 8.17 & 8.11 \\
$\begin{array}{l}\mathrm{Oxy} \\
(\mathrm{mg} / \mathrm{l})\end{array}$ & 0.1 & 0.11 & 7.38 & 8.35 \\
$\mathrm{Cond}$ & 1480 & 1077 & 1787 & 1085 \\
$(\mu \mathrm{s} / \mathrm{Cm})$ & & & & \\
$\mathrm{Mg}(\mathrm{mg} / \mathrm{g})$ & 47.95 & 56.38 & 12.71 & 49.25 \\
$\mathrm{Al}$ & 20.98 & 37.6 & 7.56 & 25.03 \\
$(\mathrm{mg} / \mathrm{g})$ & & & & \\
$\mathrm{Ca}(\mathrm{mg} / \mathrm{g})$ & 28 & 36 & 18.01 & 15.85 \\
$\mathrm{Fe}$ & 289 & 1627 & 296 & 281 \\
$(\mathrm{mg} / \mathrm{g})$ & & & & \\
$\mathrm{As}(\mu \mathrm{g} / \mathrm{g})$ & $<1$ & 10.4 & $0<1$ & $<1$ \\
$\mathrm{Cd}(\mu \mathrm{g} / \mathrm{g})$ & 1.69 & 1.47 & $<0.5$ & 10.5 \\
$\mathrm{Co}(\mu \mathrm{g} / \mathrm{g})$ & 4.75 & 11.2 & $<1$ & $<1$ \\
$\mathrm{Cr}$ & 136.23 & 415.7 & $<1$ & $<1$ \\
$(\mu \mathrm{g} / \mathrm{g})$ & & & & \\
$\mathrm{Mn}(\mu \mathrm{g} / \mathrm{g})$ & 105.3 & 40.5 & 3.83 & 3.13 \\
$\mathrm{Ni}(\mu \mathrm{g} / \mathrm{g})$ & 12.35 & 33.0 & $<1$ & $<1$ \\
$\mathrm{~Pb}(\mu \mathrm{g} / \mathrm{g})$ & 95.25 & 148.1 & $<1$ & $<1$ \\
$\mathrm{Zn}$ & 157.7 & 136.5 & $<15$ & 1.86 \\
$(\mu \mathrm{g} / \mathrm{g})$ & & & & 1.47 \\
$\mathrm{Cu}(\mu \mathrm{g} / \mathrm{g})$ & 137.5 & 81.9 & $<1$ & \\
\hline
\end{tabular}


fresh sediments, wetted with a few $\mathrm{ml}$ of ultrapure water in a 100-ml round bottom flask. This solution was heated for $2 \mathrm{~h}$. In addition, after cooling and filtration, the solution was analyzed by ICP-MS (inductively coupled plasma mass spectrometer).

A resuspension under a continuous oxygen diffusion was carried out in order to simulate the modification of the biogeochemical behavior of the metals trapped in anaerobic sediments with the physicochemical condition (oxygenation of the environment), conditions arising with big floods, withreleased water from upstream dams (sample of the station No. 5). The analysis of this sample loaded with metal elements, especially with $\mathrm{Cr}, \mathrm{Fe}$ and $\mathrm{Mn}$, was carried out in order to understand the mobility of these elements. The experiment consists in dispersing the fresh anaerobic sediment of Sebou River in oxygenated water (environment hardness), maintaining mixing by agitation and bubbling of air for 1 week. In order to limit the effect of evaporation, the reactor was placed in a closed chamber. A multi-probe $(\mathrm{pH}$, oxygen, temperature) was placed in the reactor for a continuous monitoring of the physicochemical parameters. Daily filtrations (the filtrate is acidified with suprapure nitric acid for conservation) were performed prior to ICP-MS analyses of metals. A follow-up of sulfates and COD was also carried out; the same assembly used during the resuspension in oxygenated environment was reused under acidic conditions and nitrogen atmosphere in order to show the effect of the $\mathrm{pH}$ on the mobility of the metals elements traces. The environment of mobilization was acidified with ultrapure nitric acid, in order to reach first a $\mathrm{pH}$ of 5 and then a pH of 2 .

Table 2 Comparison of maximal trace metal contents in Sebou and Fez Rivers' surface sediments in the present study and other studies of other Moroccan and international rivers

\begin{tabular}{|c|c|c|c|c|c|c|c|}
\hline Authors & River, location & Layer $(\mathrm{cm})$ & $\mathrm{Pb}(\mu \mathrm{g} / \mathrm{g})$ & $\mathrm{Zn}(\mu \mathrm{g} / \mathrm{g})$ & $\mathrm{Cr}(\mu \mathrm{g} / \mathrm{g})$ & $\mathrm{Ni}(\mu \mathrm{g} / \mathrm{g})$ & $\mathrm{Cu}(\mu \mathrm{g} / \mathrm{g})$ \\
\hline Barakat et al. (2012) & Day, Morocco & $0-10$ & 135.3 & 145.5 & 311.7 & - & 740.8 \\
\hline Singh et al. (2005) & Gomti, India & Surface & 40.3 & 41.7 & 8.15 & 15.7 & 5.0 \\
\hline Mohiuddin et al. (2010) & Tsurumi, Japan & $0-10$ & 41 & 381 & 103 & 37 & 133 \\
\hline Suresh et al. (2011) & Ponnaiyar, India & Surface & 85.2 & 182.9 & 87.3 & 29.5 & 81.8 \\
\hline Hayzoun et al. (2014) & $\begin{array}{l}\text { Sebou (downstream } \\
\text { of Fez City), } \\
\text { Morocco }\end{array}$ & $0-6$ & 100 & 236 & 115 & 46 & 171 \\
\hline Hayzoun et al. (2014) & Fez, Morocco & $0-6$ & 184 & 365 & 881 & 84 & 244 \\
\hline Present study & $\begin{array}{l}\text { Sebou (downstream } \\
\text { of Fez City), } \\
\text { Morocco }\end{array}$ & $0-10$ & 95.25 & 157.7 & 136.2 & 12.35 & 137.5 \\
\hline Present study & Fez, Morocco & $0-10$ & 148.1 & 136.5 & 415.7 & 33.0 & 81.9 \\
\hline
\end{tabular}
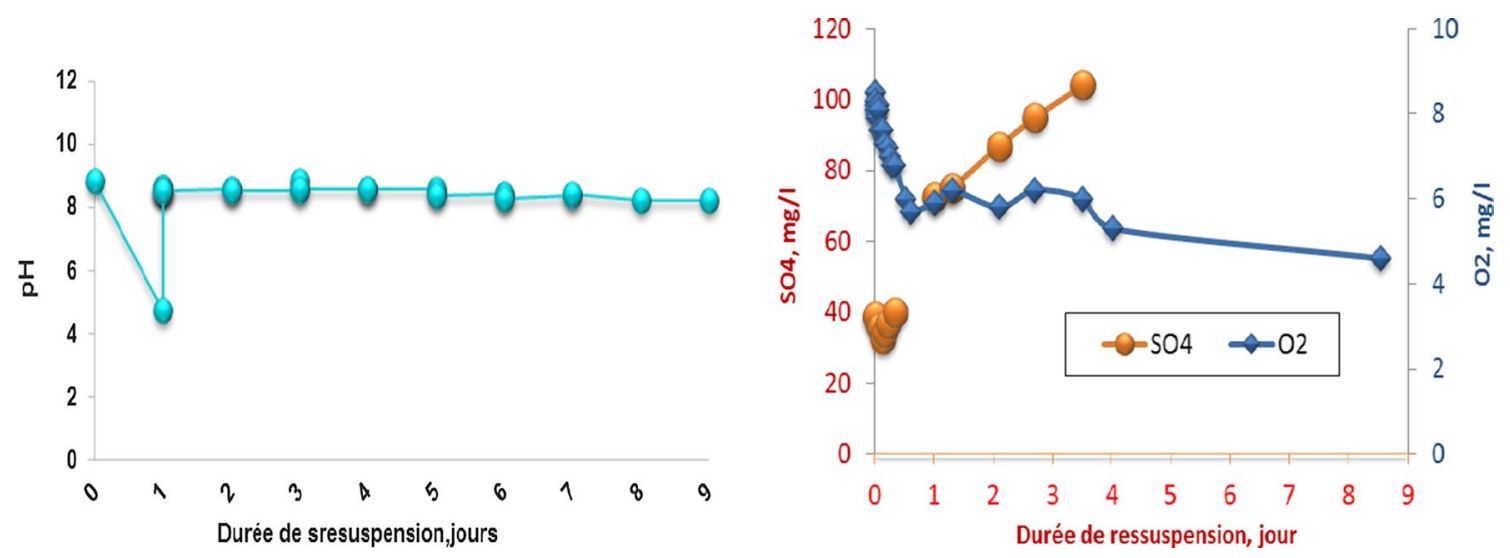

Fig. 2 Variation of oxygen dissolved $\mathrm{pH}, \mathrm{SO} 4$ and oxygenated environment during the resuspension under continuous oxygen bubbling of fresh sediment of Sebou River 


\section{Results and discussion}

Excepting the stations of reference where the dissolved oxygen rate was high, the other stations showed a clear anoxia (Table 1). In the Station No. 3 (downstream of Fez town), the electrical conductivity (EC) increased twice compared to the samples from the Station No. 1 (Table 1). The increase in the EC may be due to the discharge (industrialist, artisanal and urban) from $\mathrm{Fez}$ town wastewater, which is transferred to Fez River without any preliminary treatment (Koukal et al. 2004). In addition, the $\mathrm{pH}$ studied in the total hydrological network was basic, which is probably related to the calcareous nature of the watershed area (Table 1).

The total heavy metals contents in the sediments of Sebou River and its affluent the Fez River determined by digestion with aqua regia are represented in Table 1, which shows a progressive enhancement of the sediments in several metals: chromium $415.7 \mu \mathrm{g} / \mathrm{g}$, lead $148.1 \mu \mathrm{g} / \mathrm{g}$, nickel $33.0 \mu \mathrm{g} / \mathrm{g}$, in the downstream of Fez City. This enrichment is related to the discharge of the artisanal activities of $\mathrm{Fez}$ (tanneries and dinandery). According to Bouanani 1997, daily flows of chromium are maintained in a range of $160-320 \mathrm{~kg} / \mathrm{d}$ and conferring to Koukal et al. 2004, the daily load of chromium is $400 \mathrm{~kg} / \mathrm{d}$ and $100 \mathrm{~kg} / \mathrm{d}$ of nickel. The longitudinal variations of the concentrations in metals elements traces were explained by the sediments texture; the fine elements often consist of organic matter, clay and colloids of iron, and characterized by a great capacity of metals fixation. On the other hand, this fixation is not definitive; if the physicochemical conditions of the sedimentary medium change (Ivone et al. 2002), these deposits can become a real source of water contamination column by leading to the salting out of the trace element.

The measured concentrations of metals in the Station No. 2 and the Station No. 5: surface sediments $(0-10 \mathrm{~cm})$ were compared with those recorded in other rivers from various countries, including Morocco (Table 2). The metal concentrations measured at Fez River were superior to those recorded in heavily polluted rivers such as the Deûle (Lesven et al. 2010) that received direct discharges from metallurgical industry in this area.

During a resuspension in oxygenated environment of anoxic sediments (sample Station No. 5), the dissolved oxygen concentration decreases significantly with time and was associated with an increase in the sulfate concentrations (Fig. 2), resulted by sulfides oxidation. At the same time, the
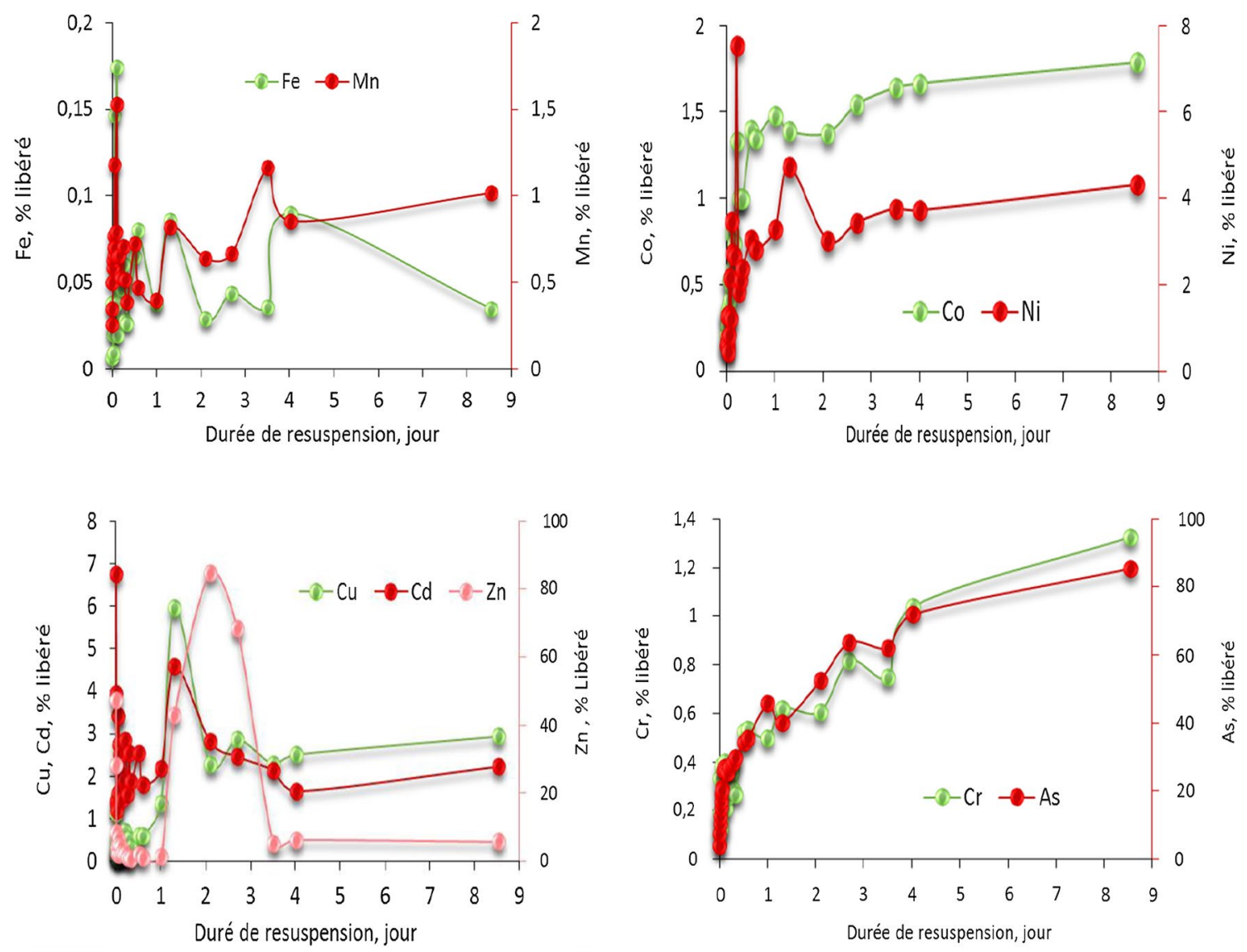

Fig. 3 Mobilization percentage EMT during the resuspension under continuous oxygen bubbling of fresh sediment of Sebou River

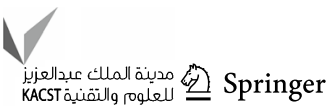


metal trace elements of $\mathrm{Cr}$, As, $\mathrm{Ni}$ and Co were released by the oxidation of the Sebou River sediment (Fig. 3). Their concentrations in the dissolved phase were increased with time. The release of these elements is related to the oxidation of the sulfides, which is probably responsible for the trapping of many metals in the sediments. This implies a risk of re-mobilization of the metal contaminants associated with the changes in the physicochemical conditions (Petersen et al. 1995). The initial oxidation of sulfides is accompanied with the oxidation of $\mathrm{Mn}$ and the precipitation of $\mathrm{Fe}$ in the form of oxides. $\mathrm{Zn}$ follows the same behavior as $\mathrm{Fe}$, which can be explained by the association of these elements in the form of oxide-hydroxides. A second phase of metals release takes place between one and three days, probably due to the oxidation of organic matter; this phenomenon was proved by the fact that oxygen concentration remains low while there is a continuous air bubbling. The concentration of all MTE (metal trace element) increases in solution and tends toward a stabilization, except for $\mathrm{Zn}, \mathrm{Cd}$ and $\mathrm{Cu}$ which precipitate after one or two days in the form of oxides (Fig. 3).
In acid $\mathrm{pH}$, the MTE becomes more mobile because the metal compounds were solubilized and their adsorption is reduced on clays (Brin 2007). During the study of the kinetics mobilization of the anaerobic sediments in acid environment (pH 5.5) (Fig. 4), the elements $\mathrm{Cr}$, As, Ni and Co were released in parallel with the release of $\mathrm{Fe}$ and $\mathrm{Mn}$ and were mobilized after $20 \mathrm{~min}$; afterward, a slow re-precipitation was observed in the following minutes. For the elements $\mathrm{Cu}, \mathrm{Cd}$ and $\mathrm{Zn}$, a fast mobilization was noted, followed by a precipitation at the same time of the $\mathrm{Fe}$ and $\mathrm{Mn}$ elements. The oxidation of these two elements allows the fast trapping by the co-precipitation of the some elements $(\mathrm{Cu}, \mathrm{Cd}$ and $\mathrm{Zn})$. The mobilization of $\mathrm{Zn}$ in the second phase coincides with the one of $\mathrm{Fe}$ or $\mathrm{Mn}$, followed by a rapid precipitation. The sediment immediately adsorbs $\mathrm{Zn}$ and this is why it is salted out again. The $\mathrm{Fe}-\mathrm{Mn}$ oxide is the phase that actively absorbs certain trace element (Tessier et al., 1996). The results of resuspension in a very acid medium showed that $\mathrm{Fe}$ and $\mathrm{Mn}$ start to be released significantly only from $\mathrm{pH}<2$ (80\% exceed) (Fig. 5). However, Cr, As, Ni, Zn and
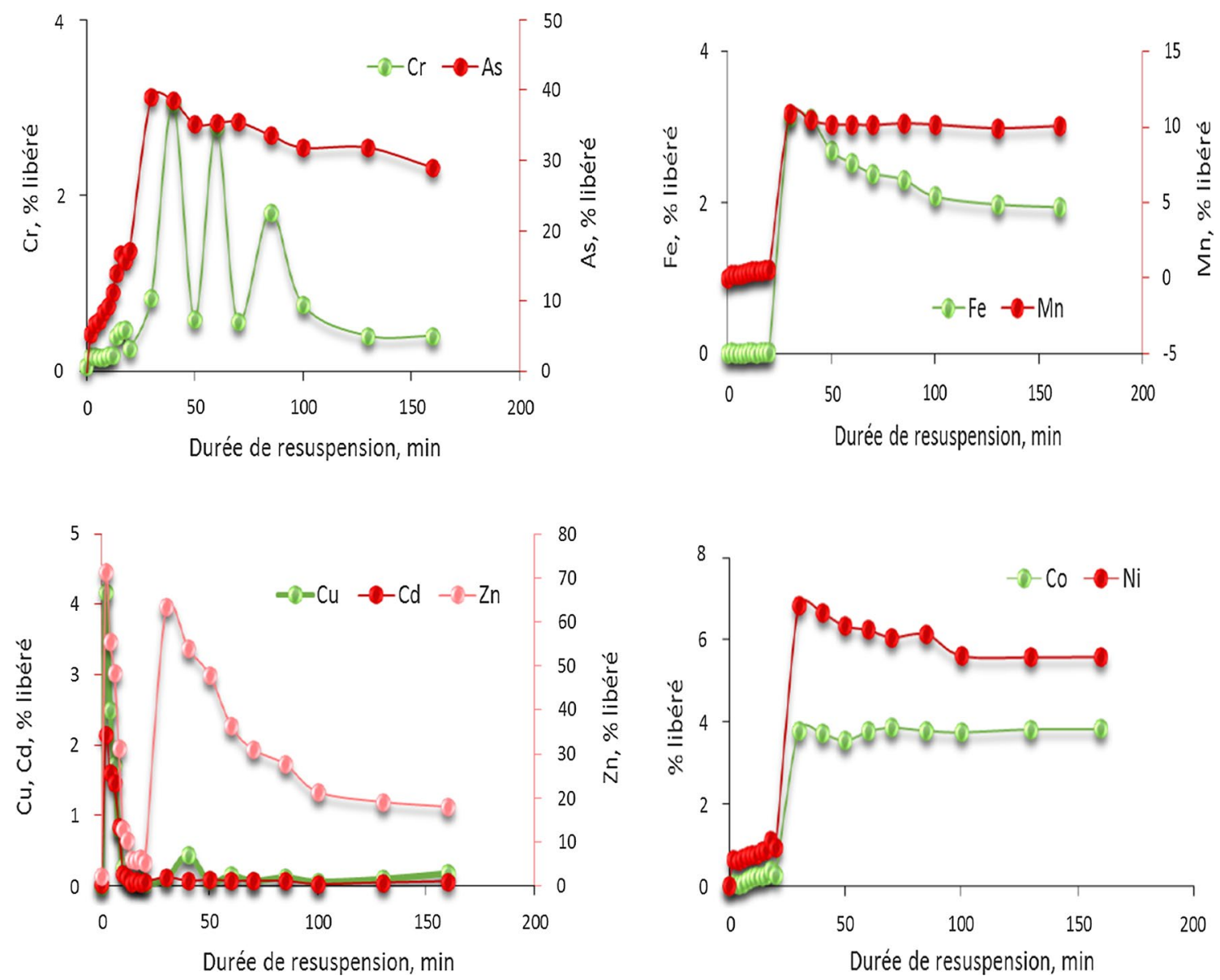

Fig. 4 Mobilization percentage (\%) EMT during the kinetics of mobilization of the sediment under reductive conditions in nitrogen atmosphere and $\mathrm{pH} 5.5$ 

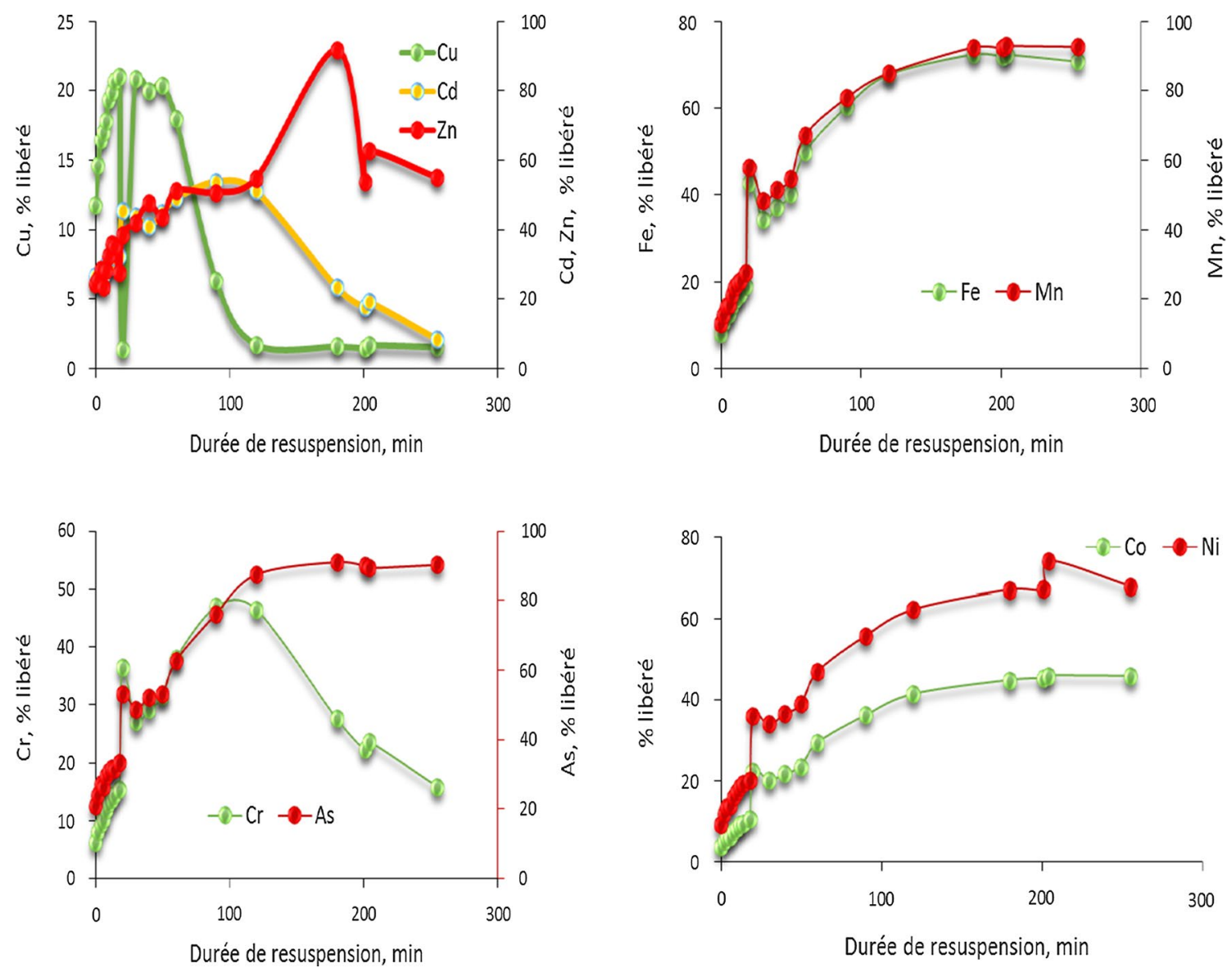

Fig. 5 Mobilization percentage (\%) EMT during the kinetics of mobilization of the sediment under reductive conditions in nitrogen atmosphere and $\mathrm{pH} 2$

Co were released jointly with $\mathrm{Fe}$ and $\mathrm{Mn}$ and $\mathrm{Cr}$ was later re-precipitated.

\section{Conclusions}

In this study, water physicochemical parameters of Fez and Sebou Rivers were studied in order to evaluate their state. The results indicate that the sampling stations located downstream from the Fez City and the confluence between Fez and Sebou Rivers were polluted (low oxygen level and high MTE levels and especially $\mathrm{Cr}, \mathrm{Cu}$ and $\mathrm{Ni}$ ). The study of the resuspension of sediments of Sebou in downstream of Fez City (Station No. 5) confirmed that the sediments were not the final traps of the metal elements traces. Moreover, when the physicochemical conditions were changed, the majority of the MTE were mobilized in aqueous environment, mainly because of the oxidation of sulfides and because some metals like $\mathrm{Cr}$ have been re-precipitated quickly with the oxidation of iron and/or manganese. On the other hand, some other elements were maintained in solution, which represents a real human health risk.
Acknowledgements The authors thank everyone who participated in the campaign of sampling and sample preparations and analysis, especially water resources laboratory members at Arlon Campus University of Liège: Mrs PLUN D, Mrs TOUSSAINT S, Mr SCHROBILTGEN P, Mr SCHEUREN C and Mr DELVAUX C. This work was financially supported by bilateral cooperation between the WALLONIE BRUXELLE INTERNATIONAL and MOROCCO.

Open Access This article is distributed under the terms of the Creative Commons Attribution 4.0 International License (http://creativeco mmons.org/licenses/by/4.0/), which permits unrestricted use, distribution, and reproduction in any medium, provided you give appropriate credit to the original author(s) and the source, provide a link to the Creative Commons license, and indicate if changes were made.

\section{References}

Amri N, Benslimane M, Zaoui H, Hamdoun M, Outiti B (2007) Evaluation of the heavy metals accumulate in samples of the sediments, soils and plants by Icp-oes with the average. Moroc J Condens Matter 8(1):43-52 
Audry S, Grosbois C, Bril H, Schäfer J, Kierczak J, Blanc G (2010) Post-depositional redistribution of trace metals in reservoir sediments of a mining/smelting-impacted watershed (the Lot River, SW France). Appl Geochem J 25:778-794

Azzaoui S, El hanbali M, Leblanc M (2002) Copper, lead, iron and manganese in the Sebou drainage basin; sources and impact on surface water quality. Water Pollut Res J Can 37(4):773-784

Barakat A, Baghdadi ME, Rais J, Nadem S (2012) Assessment of heavy metal in surface sediments of Day River at Beni-Mellal Region, Morocco. Res J Environ Earth Sci 4(8):797-806

Bouanani S (1997) Synthetic study of the data on industrial pollution of the tanneries of Fès, report/ratio for "United States Agency for International Development"

Bourgeault A, Gourlay-Francé C, Priadi C, Ayroult S, Tusseau-Vuillemin MH (2011) Bioavailability of particulate metal to zebra mussels: biodynamic modelling shows that assimilation efficiencies are site-specific. J Environ Pollut 159:3381-3389

Brin ME (2007) Study of the biodisponibility of the contaminants (metal elements traces and phosphorus) contained in the sediments of the lake Saint-Augustin (Quebec) University Laval Quebec. www.obvcapitale.org/wp-content/uploads/2012/07/ ULaval-2007-Biodisponibilité-des-contaminants-des-sédimen ts-du-LSA.pdf. Accessed 25 June 2014

Cantwell MG, Burgess RM, King JW (2008) Resuspension of contaminated field and formulated reference sediments Part I: evaluation of metal release under controlled laboratory conditions. Chemosph J 73:1824-1831

Derwich E, Beziane Z, Benabidate L, Belchyti D (2008) Evaluation of the water quality of surface of Fès wadi and Sebou used in marketgardening agriculture In Morocco. Larhyss J 7:59-77

Duc TA, Loi VD, Thao TT (2013) Partition of heavy metals in a tropical river system impacted by municipal waste. J Environ Monit Assess 185:1907-1925

Foudeil S, Bounouira H, Embarch K, Amsil H, Bounakhla M, AitLyazidi $S$ et al (2013) Evaluation of pollution in heavy metals in the Sebou river (Morocco). Revue Science Lib Editions Mersenne 5:2111-2470

Hassimi H, Taleb A, Bouezmarni M, Kherbeche Taleb M, Debbaut V (2016) The metal elements traces dregs with the unstable fraction of the sediment of Sebou which risk? J Mater Environ Sci 7(7):2267-2276

Hayzoun H, Garnier C, Durrieu G, Lenoble V, Bancon MC, Ouammou A et al (2014) Impact of rapid urbanisation and industrialisation on river sediment metal contamination. J Environ Monitor Assess. https://doi.org/10.1007/s10661-013-3585-5

Hayzoun H, Garnier C, Durrieu G, Lenoble V, Le Poupon C, Angeletti B et al (2015) Organic carbon, and major and trace element dynamic and fate in a large river subjected to poorly-regulated urban and industrial pressures (Sebou River, Morocco). J Sci Tot Environ 502:296-308

Ivone S, Gilberto A, Jaim L, Jorge CM (2002) Heavy metal distribution in recent sediments of the Tiete^-Pinheiros river system in Sao Paulo state, Brazil. J Appl Geochem 17:105-116

Kelderman P, Osman A (2007) Effect of redox potential on heavy metal binding forms in polluted canal sediments in Delft (The Netherlands). J Water Res 41:4251-4261

Koukal B, Dominik J, Vignati D, Arpagaus P, Santiago S, Ouddane B et al (2004) Assessment of water quality and toxicity of polluted Rivers Fès and Sebou in the region of Fès (Morocco). J Environ Pollut 131:163-172

Koukal B, Rossé P, Reinhardt A, Ferrari P, Wilkinson KJ, Loiseau JL, Dominik J (2007) Effect of pseudokircheneriella subcapitata (chlorophyceae) exudates on metal toxicity and colloid aggregation. Water Res 41(1):63-70
Kramer JR, Allen HE (1988) Metal speciation: theory, analysis and application. Lewis Publishers, Chelsea

Lafabrie C, HlailiA S, Leboulanger C, Tarhouni I, Othman HB, Mzoughi $\mathrm{N}$ et al (2013) Contaminated sediment resuspension induces shifts in a phytoplankton structure and function in a eutrophic Mediterranean lagoon. J Knowl Manag Econ Inf Technol. https://doi.org/10.1051/kmae/2013060

Lamhasni N, Chillasse L, Abba H, El Haouat S, EL Madani M (2013) Typologie des eaux de surface du bassin du Sebou par multiapproche: corrélation entre indice biologique global des réseaux de contrôle et de surveillance (IBG-RCS) et l'approche physicochimique et microbiologique. J Afr Sci 09(2):35-49

Lesven L, Lourino-Cabana B, Billon G, Recourt P, Ouddane B, Mikkelsen $\mathrm{O}$ et al (2010) on metal diagenesis in contaminated sediments of the Deûleriver (northern France). J Appl Geochem 25(9):1361-1373

Lourino-Cabana B, Lesven L, Billonn G, Proix N, Recourt P, Ouddane $B$ et al (2010) Impact of metal contamination in Calcareous Waters of Deûle River (France): water quality and thermodynamic studies on metallic mobility. J Water Air Soil Pollut 206:187-201

Malki M, Marin I, Essahale A, Amils R, Moumni M (2008) Physicochemical parameters and bacterial diversity in the Moroccan's Sebou River. J Food Agric Environ 6:172-176

Meers E, Unamuno V, Vandegehuchte M, Vanbroekhoven K, Geebelen W, Samson R et al (2005) Soil-solution speciation of Cd as affected by soil characteristics in unpolluted and polluted soils. $\mathrm{J}$ Environ Toxicol Chem 24:499-509

Mohiuddin KM, Zakir H, Otomo K, Sharmin S, Shikazono N (2010) Geochemical distribution of trace metal pollutants in water and sediments of downstream of an urban river. Int J Environ Sci Technol 7(1):17-28

Mutin G (2009) Le Monde arabe face au défi de l'eau. Enjeux et Conflits. Institut d'Etudes Politiques de Lyon. Hal-00352860, version 2., p 164

Perrin JL, Rais N, Chahinian N, Moulin P, Ijjaali M (2014) Waterqualityassessment of highlypollutedrivers in a semi-aridMediterraneanzoneOued Fès and Sebou River (Morocco). J Hydrol 512:26-34

Petersen W, Wallman K, Pinglin L, Schroeder F, Knauth HD (1995) Exchange of trace elements at the sediment-water interface during early diagenesis processes. J Mar Freshwater Res 46:19-26

Singh KP, Mohan D, Singh VK, Malik A (2005) Studies on distribution and fractionation of heavy metals in Gomti river sediments - a tributary of the Ganges. India. Journal of Hydrology 312(1-4):14-27

Suresh G, Ramasamy V, Meenakshisundaram V, Venkatachalapathy R, Ponnusamy V (2011) Influence of mineralogical and heavy metal composition on natural radionuclide concentrations in the river sediments. Appl Radiat Isot 69(10):1466-1474

Tessier A, Campbell PGC, Bisson M (1979) Sequential extraction procedure for the speciation of particulate trace metals. J Anal Chem 51:844-851

Tessier A, Fortin D, Belzile N, DeVitre RR, Leppard GG (1996) Metal sorption to diagenetic iron and manganese oxyhydroxides and associated organic matter: narrowing the gap between field and laboratory measurements. J Geochim Cosmochim Acta 60:387-404

Publisher's Note Springer Nature remains neutral with regard to jurisdictional claims in published maps and institutional affiliations. 